\title{
Investigation through New Approach on Plants with Antihypertensive Properties Used by the Herbalists in the Maritime Region of Togo
}

\author{
Souleymane Compaoré ${ }^{*}$, Koffi Koudouvo², Alimata Bancé ${ }^{1}$, Raïnatou Boly ${ }^{1}$, \\ Lazare Belemnaba ${ }^{1}$, Noufou Ouédraogo ${ }^{1}$ and Sylvin Ouédraogo ${ }^{1}$ \\ ${ }^{1}$ Department of Medicine, Traditional Pharmacopoeia and Pharmacy (MEPHATRA/PH), Institute for \\ Research in Health Sciences (IRSS), 03 BP 7047, Ouagadougou, Burkina Faso. \\ ${ }^{2}$ Laboratory of Physiology and Pharmacology of Natural Products, Faculty of Sciences,
} University of Lomé, Togo.

Authors' contributions

This work was carried out in collaboration among all authors. Author SC designed the study, performed the statistical analysis and wrote the protocol. Authors SC, KK and AB wrote the first draft of the manuscript. Authors RB, LB and NO managed the analyses of the study. Author SO managed the literature searches. All authors read and approved the final manuscript.

Article Information

DOI: $10.9734 / A R R B / 2020 / v 35 i 1230316$ Editor(s):

(1) Dr. Bechan Sharma, University of Allahabad, India.

Reviewers:

(1) Lilia Gama, Universidad Juarez Autonoma de Tabasco, Mexico. (2) Neuza Rejane Wille Lima, Fluminense Federal University, Brazil. Complete Peer review History: http://www.sdiarticle4.com/review-history/64157

Original Research Article

Received 15 October 2020

Accepted 27 December 2020

Published 28 December 2020

\section{ABSTRACT}

Like other countries in sub-Saharan Africa, hypertension is currently a public health problem in Togo. To decrease the insufficient of the methods previously used, a new survey technique, namely ATRM (Achat en Triplet des Recettes Médicinales), has been proposed. This study aims to contribute to a better knowledge of traditional remedies for their safe and sustainable use in the management of hypertension. ATRM method applied with 34 herbalists of 17 markets in maritime and Lomé-Commune health regions. Plant species and parts used, preparation and administration methods and market characteristics of plants were collected. In total, 62 plant species (56 genera and 30 families) were identified from 102 collected recipes. These recipes included $70 \%$ single plant recipes and $30 \%$ associated plant recipes, showing the influence of the ATRM method in reducing the number of plants in the recipes. Lippia multiflora Moldenke $(23.50 \%)$ was the most 
used plant species followed by Uvaria chamae P. Beauv (8.20\%), Acanthospermum hispidum DC. $(4.92 \%)$, Lannea kerstingii A. Rich. (3.83\%), Vitex doniana Sweet $(3.83 \%)$, and Senna sieberiana DC. $(3.28 \%)$. Leafy stems $(33.33 \%)$, roots $(20.83 \%)$ and trunk bark $(16.67 \%)$ were the most used organs. The recipes were mainly prepared as a decoction and administered orally. In the transit market, Sorghum bicolor (L.) Moench (7.12 USD/kg), Senna occidentalis (L.) Link (4.98 USD/kg), Senna angustifolia Vahl (3.73 USD/kg) and Gardenia aqualla Stapf. \& Hutch. (3.56 USD/kg) were the most expensive plants. $59.18 \%$ of the plant parts sold were roots, fruits, seeds, trunk bark and whole plants. These results suggest, on the one hand, an extensive biological investigation for effective management of hypertension. On the other hand, there is an urgent need to preserve the species whose vital organs were heavily sold.

Keywords: Ethnobotanical investigation; hypertension; monetary value; Togo.

\section{INTRODUCTION}

Hypertension, a major cardiovascular risk factor, has become an important public health challenge worldwide [1-4]. More than $25 \%$ of adults worldwide were suffering from this disease. This proportion is expected to rise in the coming years. In Sub-Sahelian Africa, it is estimated that 150 million persons will be hypertensive by 2025 [5]. Its prevalence rate in professional settings in Togo is $28.9 \%$ [6]. In neighboring Benin and Burkina Faso, the rates were respectively $27.9 \%$ [7] and $17.3 \%$ in 2014 [8]. Several studies indicated that prevalence among urban populations is higher than their counterparts in rural areas and increases with age $[9,10]$. The consequences of the disease are target organ damage such as the heart, kidneys, brain, or retina [11,12]. Although conventional medicines exist in Togo for the treatment of hypertension, herbal medicines have often maintained a population for historical and cultural reasons [13]. However, the process of harvesting medicinal plants often constitutes a threat to their survival, and herbalists are one of the main actors [14]. In addition, the patterns of traditional drugs use are not always appropriate. This sometimes poses a problem of safety and therapeutic failure.

Important studies already conducted with traditional healers in Togo have shown how plants are used in the management of hypertension and diabetes [4,15]. The approaches used were mainly based on semistructured interviews (SSI) that nowadays have some inadequacies due to the mistrust of traditional healers towards the world of research. The present study adopted the "ATRM" method (Achat en Triplet des Recettes Médicinales) developed by Koudouvo et al. [16] to limit these deficiencies. This study aimed to contribute to a better knowledge of traditional remedies for their safe and sustainable use in the management of hypertension. Specifically, it was:
- Evaluate the number of recipes sold in the Lomé markets for the management of hypertension

- Determine the floristic composition of the plants sold in the markets of Lomé city

- Determine the frequency of citation of plants sold in the markets of the Lomé city for the management of hypertension

- Evaluate the prices of plant organs sold in the markets of the city of Lomé for the management of hypertension

\section{MATERIALS AND METHODS}

\subsection{Study Framework}

The study was conducted in July 2017 in two health regions: Lomé-commune and maritime health regions (Fig. 1). This zone is located between $1^{\circ} 20^{\prime}$ to $1^{\circ} 50^{\prime} \mathrm{W}$ and $6^{\circ} 10^{\prime}$ south latitude to $6^{\circ} 60$ ' $\mathrm{N}$, with an area of $6,100 \mathrm{~km}^{2}$ it is limited at the South part by the Atlantic Ocean, the North by the Health Region of Plateau, the East, and the West respectively by the Benin Republic and Republic of Ghana [17]. The climate of this area is sub-equatorial, characterized by a long rainy season from March to July (maximum in June: $1200 \mathrm{~mm}$ ), and a short rainy season from September to November (maximum in October: $1000 \mathrm{~mm}$ ). The minimal precipitations for these two seasons are 184.4 $\mathrm{mm}$ and $6.9 \mathrm{~mm}$, respectively. The average annual temperature is around $27.5^{\circ} \mathrm{C}$ with a maximum of around $35.1^{\circ} \mathrm{C}$ in the warm season [18]. This zone is highly degraded, the vegetation is composed of disparate forests, relics of gallery forests, savannahs, grasslands, coastal thickets, or halophilic swamps. The region is inhabited by $1,828,000$ people (density of 50 200 persons $/ \mathrm{km}^{2}$ ), the main ethnic groups being Ewe, Ouatchi, Mina, Fon, Adja [19,20]. 


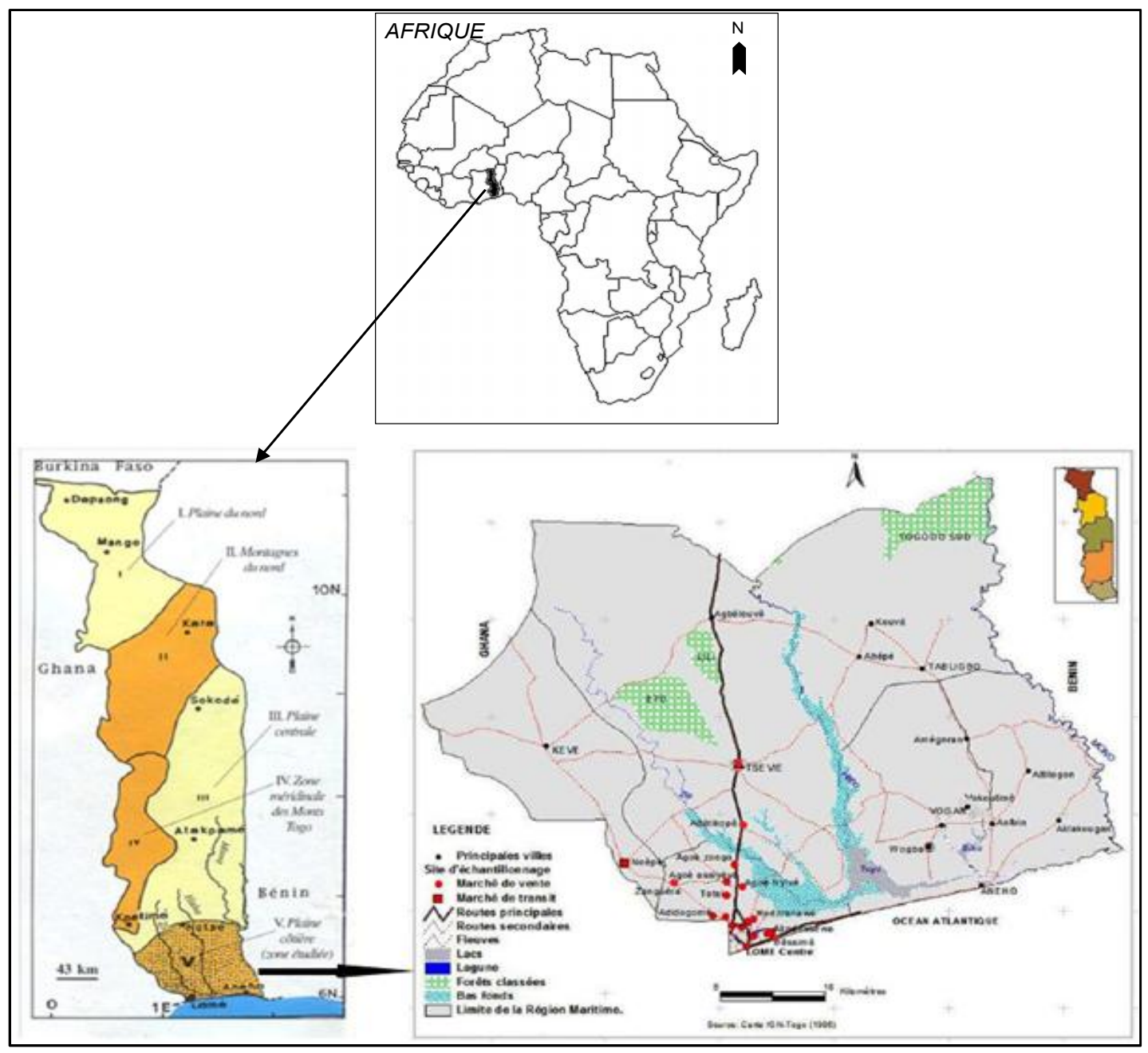

Fig. 1. Map of the study area

A map of the African continent, indicating the location of Tog is required.

\subsection{Data Collection}

The ATRM (Achat en Triplet des Recettes Médicinales) method was used to collect the data. Its already successfully tested in several works $[14,17,18]$. This method was carried out with 34 herbalists of 17 markets in July 2017 in maritime and Lomé-Commune health regions. These were the markets of Ablodessimè, Adamavo, Adidogomè, Agoè-Assiyéyé, Agoè-Atchanvé, Agoè-Zongo, Ahanoukopé, Ahligo, Akodesséwa, Attikpodji, Bessimè, Gbossimè, Hédzranawoé, Kélégougan, Nukafu, Totsi and Zanguera (Fig. 1). The method of ATRM consisted of visiting market herbalists three times separated by one week, to buy recipes of plants used in the treatment of hypertension. The three successive visits to the markets of sale (MS) were to buy medicinal plant recipes respectively in a large number (LN), reduced number $(\mathrm{RN})$ and much reduced number (MR) or single plant (SP). The process was to attend the issue of the smallest number of plants in recipes for management of hypertension by the same practitioner. For each recipe, local names and plants organs used, therapeutic indications, mode of preparation and routes of administration were recorded. Recipes weight, price, and physical nature (fresh or dry) were also noted Koudouvo et al. [14]. After the surveys with an herbalist, three transaction markets (Noépé, Tsiévié and Akodessewa) were also visited. In these markets, plant materials have been purchased, their local name, weight and price were noted. 


\subsection{Data Analysis}

Botanical identification of species collected was performed according to APG (Angiosperms Phylogeny Group) III, [21] and the Analytical Flora of Benin [22]. Pr. K. Akpagana conducted confirmation of Latin names, and the local names were verified through previous ethnobotanical surveys. The Windows.10 Excel spreadsheet and SPSS 20.0 software were used for data processing and analysis. The citation frequency (Fc) of each plant species and their use value (UV) were determined by the following formulas $[13,20]$ :

$$
\mathrm{Fc}=\mathrm{Fi} / \mathrm{n}
$$

where $\mathrm{Fi}$ is the number of citations of the species, $\mathrm{n}$ the total number of recipes.

$$
\mathrm{UV}=\Sigma \mathrm{U} / \mathrm{n}
$$

Where UV is the use value of a species, $U$ the number of citations per species, $\mathrm{N}$ the number of informants

\section{RESULTS AND DISCUSSION}

\subsection{Quantity of Recipes Sold in the Lomé Markets for the Management of Hypertension}

In total, 102 recipes were collected from 34 herbalists in the 17 markets. These medicinal recipes were composed of 62 plant species. In general, the results (Table 1 ) indicate a decrease in the number of plants per recipe from the first to the third purchase from herbalists. The total number of plants per market was the number of plant species recorded during the three visits and not the sum of the plants per recipe. The market of Agoè-Assiyéyé presented the largest number of plants [19], representing $30.64 \%$ of the total number. The unique plant recipes erehigher $(\mathrm{UR}=70 \%)$ than the associated plant recipes (AR) collected and the number of plants per recipe varied from one to twelve. Thus, the recipes with two associated plants $(A R=2)$, the recipes with three associated plants $(A R=3)$ and those with more than three associated plants $(A R>3)$ represented respectively $12 \%, 5 \%$, and $13 \%$ of all recipes (Fig. 2). The high proportion of unique recipes would be related to the survey method used, which certainly reduced the number of recipes proposed by herbalists. It may also be due to low knowledge of hypertension among the herbalists surveyed. These results were different from those of Karou et al. [17], who, using the semi-structured interview method, identified twenty-one recipes of associated plants $(60 \%)$ and fourteen unique plant recipes $(40 \%)$ with a maximum of eight plants per recipe. Thirteen recipes $(12.75 \%)$ sold by herbalists for the management of hypertension were each composed of more than three plants (Fig. 2). According to Karou et al. [17], these recipes should be used with care because of the limitless compounds that could occur in one plant.

\begin{tabular}{|c|c|c|c|c|c|c|c|}
\hline \multirow[t]{2}{*}{ Markets } & \multicolumn{3}{|c|}{ Herbalist 1} & \multicolumn{3}{|c|}{ Herbalist 2} & \multirow[t]{2}{*}{ Total } \\
\hline & LN & RN & MR & LN & RN & MR & \\
\hline Ablodessimè & 3 & 2 & 2 & 11 & 6 & 2 & 15 \\
\hline Adamavo & 2 & 1 & 1 & 1 & 1 & 1 & 4 \\
\hline Adidogomè & 6 & 1 & 1 & 2 & 1 & 1 & 7 \\
\hline Agoè-Assiyéyé & 12 & 2 & 1 & 6 & 2 & 1 & 19 \\
\hline Agoè-Atchanvé & 1 & 1 & 1 & 1 & 1 & 1 & 4 \\
\hline Agoè-Zongo & 1 & 1 & 1 & 1 & 1 & 1 & 5 \\
\hline Ahanoukopé & 1 & 1 & 1 & 1 & 1 & 1 & 3 \\
\hline Ahligo & 4 & 1 & 1 & 1 & 1 & 1 & 6 \\
\hline Akodesséwa & 1 & 1 & 1 & 1 & 1 & 1 & 2 \\
\hline Attikpodji & 3 & 1 & 2 & 4 & 1 & 1 & 8 \\
\hline Bessimè & 1 & 2 & 1 & 1 & 1 & 1 & 5 \\
\hline Gbossimè & 5 & 1 & 1 & 1 & 1 & 1 & 6 \\
\hline Hédzranawoé & 3 & 1 & 1 & 4 & 1 & 1 & 6 \\
\hline Kélégougan & 1 & 6 & 5 & 1 & 1 & 1 & 9 \\
\hline Nukafu & 7 & 2 & 3 & 1 & 1 & 1 & 12 \\
\hline Totsi & 8 & 1 & 2 & 1 & 1 & 1 & 9 \\
\hline Zanguera & 3 & 1 & 1 & 2 & 1 & 1 & 5 \\
\hline
\end{tabular}

Table 1. Number of plants collected by ATRM in each 17 markets 


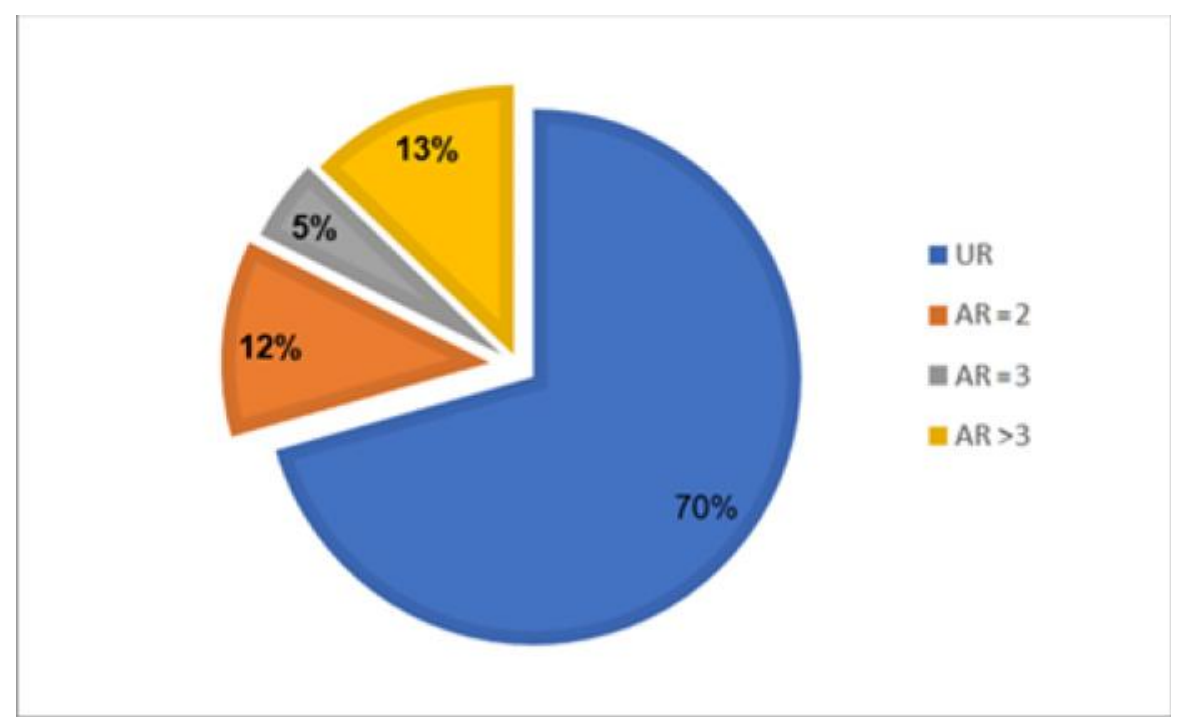

Fig. 2. Frequency of recipes (AR: associated plant recipes; UR: unique plant recipes)

$3.5 \%-2.12 \% 3.13 \%-$ UR $71 \%$

The values have been corrected in the graph above

\subsection{Floristic Composition and Frequency of Plants Citation}

Sixty-two (62) plant species belonging to 56 genera and 30 families were recorded by the ATRM method. The family of Fabaceae $(13.79 \%)$, Rubiaceae $(10.33 \%)$ and Poaceae $(6.90 \%)$ were the most represented, followed by Anacardiaceae, Apocynaceae, Bignoniaceae, Malvaceae and Phyllanthaceae were each represented by $5.17 \%$ of species total number (Fig. 3). The Fabaceae family contributed with 8 species namely Mezoneuron benthamianum Baill., Parkia biglobosa (Jacq.) Benth., Piliostigma thonningii (Sch.) Miln. Redh., Senna alexandrina Mill., Senna occidentalis (L.) Link, Senna rotondifolia L., Senna sieberiana DC., Tetrapleura tetraptera (Schumach. et Thonn.) Taub.

Two species were cited in each family of Araceae, Connaraceae, Euphorbiaceae and Meliaceae, while the other families were each mentioned only once during the study. Fabaceae, Euphorbiaceae, Malvaceae, Apocynaceae, Asteraceae have also been cited as predominant families in ethnobotanical surveys for the management of hypertension in Togo [4], Nigeria [23], South Africa [24], and Cameroun [25]. Lippia multiflora Moldenke
$(23.50 \%)$ was the most used plant species. These species erefar followed by Uvaria chamae P. Beauv (8.20\%), Acanthospermum hispidum DC. (4.92\%), Lannea kerstingii A. Rich. (3.83\%), Vitex doniana Sweet (3.83\%), and Senna sieberiana DC. (3.28\%). Twenty-seven species or $46.55 \%$ of the total number were cited once with a frequency of $0.55 \%$ (Table 2). Other authors have already proved the anti-diuretic activities and hypotensive properties of some of the most cited plants. Indeed, in Benin, Gbenou et al. [26] observed anti-diuretic activities of Acanthospermum hispidum, Crateva adansonii and Uvaria chamea on normal Wistar rats. Moreover, studies carried out in Nigeria and Congo respectively have shown hypotensive effects of Vitex doniana stem bark [27], and Lippia multiflora leaves extracts [28] on normal rats. Recent studies have shown that Senna sieberiana (Cassia sieberiana) was strongly used by three associations of traditional healers in Burkina Faso for the management of hypertension [29]. Despite their low frequency of citation, other studies have also highlighted the antihypertensive effects of seeds and trunk bark of $P$. biglobosa [30-32] and trunk bark of Anogeissus leiocarpa [33].

\subsection{Patterns Use of Plants for the Manag- ement of Hypertension}

Leafy stems (33.33\%) are the most used in recipes sold by herbalists for the management of hypertension. These plant parts are followed by roots $(20.83 \%)$, trunk bark $(16.67 \%)$ then leaves 
Table 2. Species cited by 34 herbalists of 17 markets in maritime and Lomé-Commune health regions for management of hypertension

\begin{tabular}{|c|c|c|}
\hline Species of plants & Family & Frequency of citation \\
\hline Lippia multiflora Moldenke & Verbenaceae & 23.5 \\
\hline Uvaria chamae P. Beauv. & Annonaceae & 8.20 \\
\hline Acanthospermum hispidum DC. & Asteraceae & 4.92 \\
\hline Lannea kerstingii A. Rich. & Anacardiaceae & 3.83 \\
\hline Vitex doniana Sweet & Lamiaceae & 3.83 \\
\hline Senna sieberiana DC. & Fabaceae & 3.28 \\
\hline Cymbopogon citratus (DC.) Stapf & Poaceae & 2.19 \\
\hline Dichapetalum madagascariense (DC.) Keay. & Dichapetalaceae & 2.19 \\
\hline Piliostigma thonningii (Sch.) Miln. Redh. & Fabaceae & 2.19 \\
\hline Sanseviera liberica Ger. and Labr. & Agavaceae & 2.19 \\
\hline Waltheria indica L. & Malvaceae & 2.19 \\
\hline Anchomanes difformis (Blume) Engl. & Araceae & 1.64 \\
\hline Cocos nucifera L. & Arecaceae & 1.64 \\
\hline Crataeva religiosa Forst & Capparaceae & 1.64 \\
\hline Gardenia ternifolia Schumach. \& Thonn. Ssp. ternifolia & Rubiaceae & 1.64 \\
\hline Hibiscus sabdariffa L. & Malvaceae & 1.64 \\
\hline Moringa oleifera L. & Moringaceae & 1.64 \\
\hline Sarcocephalus latifolius (Smith) Bruce & Rubiaceae & 1.64 \\
\hline Senna occidentalis (L.) Link & Fabaceae & 1.64 \\
\hline Senna rotondifolia $\mathrm{L}$. & Fabaceae & 1.64 \\
\hline Eucalyptus citriodora Hooker & Myrtaceae & 1.09 \\
\hline Kigelia africana (Lam.) Benth. & Bignoniaceae & 1.09 \\
\hline Mangifera indica $\mathrm{L}$. & Anacardiaceae & 1.09 \\
\hline Oldenlandia corymbosa L. & Rubiaceae & 1.09 \\
\hline Paullinia pinnata $\mathrm{L}$. & Sapindaceae & 1.09 \\
\hline Pavetta corymbosa (DC.) F. N. Williams & Rubiaceae & 1.09 \\
\hline Pavetta crassipes K.Schum. & Rubiaceae & 1.09 \\
\hline Phyllanthus amarus Sch. et Th. & Phyllanthaceae & 1.09 \\
\hline Securidaca longepedunculata Fres. & Polygalaceae & 1.09 \\
\hline Securinega virosa (Reyb.) Baill. & Euphorbiaceae & 1.09 \\
\hline Vitellaria paradoxa Gaertn C. F & Sapotaceae & 1.09 \\
\hline Alstonia boonei De Wild. & Apocynaceae & 0.55 \\
\hline Anogeissus leiocarpa (DC.) Guill. \& Perr. & Combretaceae & 0.55 \\
\hline Bambusa vulgaris Schrad ex. Wendel & Poaceae & 0.55 \\
\hline Bridelia ferruginea Benth. & Phyllanthaceae & 0.55 \\
\hline Byrsocarpus coccineus Sch. et Th. & Connaraceae & 0.55 \\
\hline Calotropis procera (Aiton) R.Br. & Apocynaceae & 0.55 \\
\hline Clausena anisata (Wild.) Hook. F.ex Benth. & Rutaceae & 0.55 \\
\hline Cola millenii K. Schum. & Malvaceae & 0.55 \\
\hline Cymbopogon giganteus (Hochst.) Chiov. & Poaceae & 0.55 \\
\hline Gomphrena celosioides Mart. & Amaranthaceae & 0.55 \\
\hline Hymenocardia acida Tul. & Phyllanthaceae & 0.55 \\
\hline Jatropha gossypifolia L. & Euphorbiaceae & 0.55 \\
\hline Khaya anthoteka C. DC. & Meliaceae & 0.55 \\
\hline Khaya senegalensis (Desr.) A. Juss. & Meliaceae & 0.55 \\
\hline Lactuca taraxacifolia (Willd.) Schum. & Asteraceae & 0.55 \\
\hline Maytenus senegalensis (Lam.) Exell. & Celastraceae & 0.55 \\
\hline Mezoneuron benthamianum Baill. & Fabaceae & 0.55 \\
\hline Morinda lucida Benth. & Rubiaceae & 0.55 \\
\hline Newbouldia laevis Seem. & Bignoniaceae & 0.55 \\
\hline Parkia biglobosa (Jacq.) Benth. & Fabaceae & 0.55 \\
\hline Rauvolfia vomitoria Afzel. & Apocynaceae & 0.55 \\
\hline Rourea coccineus Schum et Thonn. & Connaraceae & 0.55 \\
\hline Senna angustifolia Vahl & Fabaceae & 0.55 \\
\hline Sorghum bicolor L.) Moench & Poaceae & 0.55 \\
\hline Spathodea campanulata P. Beauv. & Bignoniaceae & 0.55 \\
\hline Spondia mombin L. & Anacardiaceae & 0.55 \\
\hline Tetrapleura tetraptera (Schumach. et Thonn.) Taub. & Fabaceae & 0.55 \\
\hline
\end{tabular}




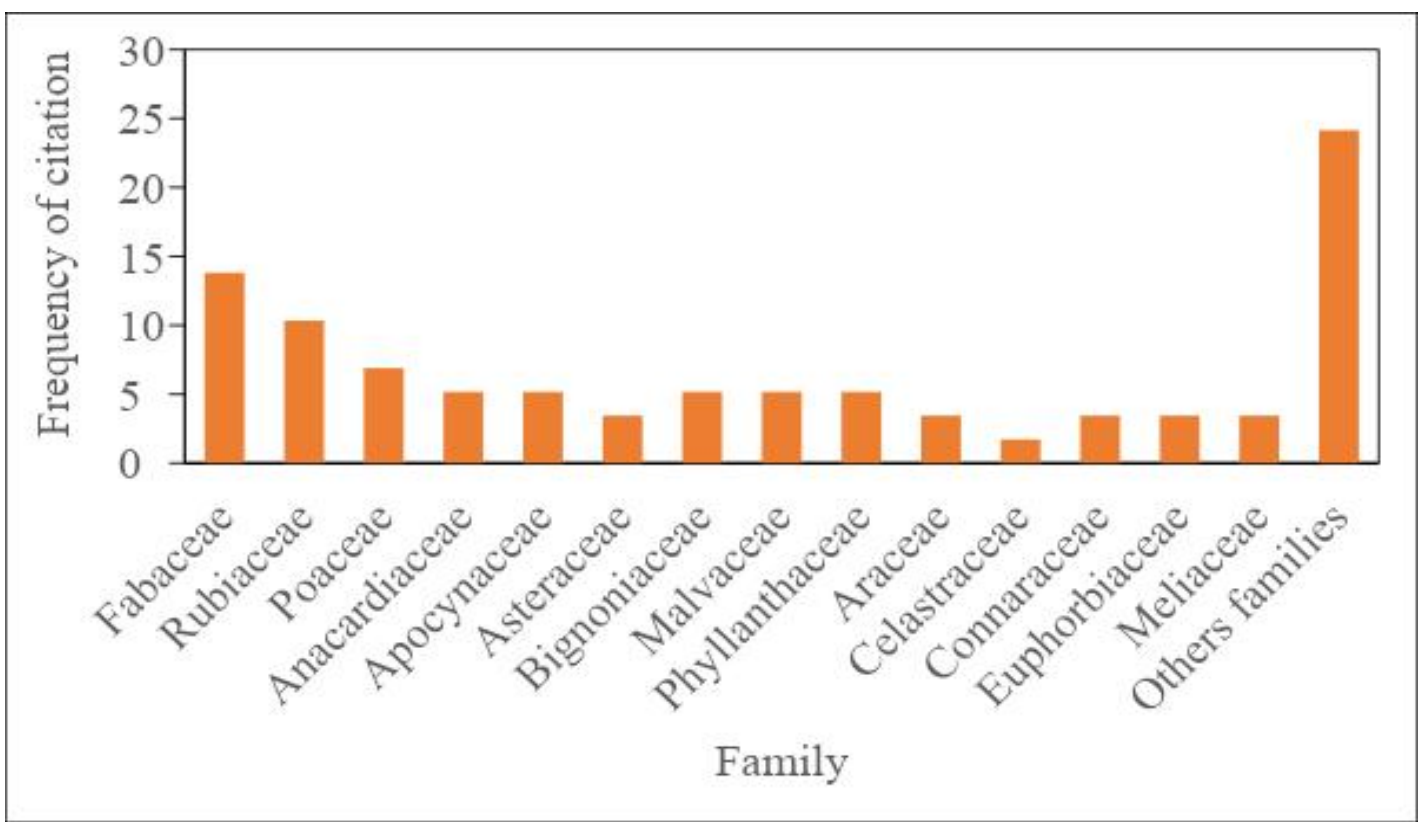

Fig. 3. Spectrum of plant families sold by herbalists in Togo, African

$(15.28 \%)$. Organs such as the whole plant and others (fruit, seeds, and tuber) are lightly used (less than 10\%) (Fig. 4). Indeed, the harvesting of leafy stems is much easier; they are accessible and often at hand. Moreover, their harvest does not strongly compromise the life span of the plant. On the other hand, roots and trunk bark are difficult to access, and their heavy use can be prejudicial to the life plant [34]. Indeed, the recurrent and anarchic removal of bark weakens the plant and makes it vulnerable to bad weather and parasite attacks [35]. The decoction and the oral route are respectively, the main modes of formulation and administration of the recipes (Fig. $5 \mathrm{ab})$. These results corroborate those of other authors' studies [29,36,37]. According to Salhi et al. [38], the decoction is a method of preparation which allows obtaining the maximum of active ingredients, reduces or cancels the toxic effects of certain recipes.

\subsection{Monetary Value and the Disadvantages of the Sale of the Antihypertensive Plant on Biodiversity}

The leaves, trunk bark, roots, or leafy stems of 49 species were found and paid in transit markets. The prices range from 13 FCFA per $\mathrm{kg}$ (0.02 USD/kg) to 4,000 FCFA per kg (7.12 USD/kg). Indeed, Sorghum bicolor (especially the leaves) is the most expensive plant (7.12 USD/kg) in the markets visited. This plant is followed by Senna occidentalis (4.98 USD/kg); Senna angustifolia (3.73 USD/kg) and Gardenia aqualla (3.56 USD $/ \mathrm{kg}$ ) (Table 3). In the same markets of the city of Lomé, Koudouvo et al. [14] had collected 16 antimalarial plants at prices ranging from 0.8 (leaves of Parkia biglobosa) to 7.2 USD/kg (Stem bark of Alstonia boonei). More than half (51.02\%) of the species inventoried are sold at more than 200 FCFA per kg (0.36 USD/kg). Moreover, $59.18 \%$ of the plant parts sold are roots, fruits, seeds, trunk bark, and whole plants, which are the sensitive organs of plants. Although the sale of the plants brings money to the people in rural areas, it is nevertheless deplorable that this can lead to the disappearance of species that are exploited anarchically or wrongly. This is the case of species such as Alstonia boonei, Lannea kerstingii, Cola millenii, Pavetta corymbosa, Uvaria chamae, Senna occidentalis, and Securidaca longepedunculata which are most used in the treatment of hypertension and whose vital organs are expensive in the markets. Previous studies have already shown that most of these species are threatened with extinction in Togo $[39,40]$. The immediate consequence of the disappearance of these species will be a reduction of availability of the ecosystem service they provide [41]. This situation suggests the adoption of urgent strategies to preserve these species of interest for hypertension. 
Table 3. Market characteristics of plants

\begin{tabular}{|c|c|c|c|c|}
\hline Species & Organs & Weight (g) & $\begin{array}{l}\text { Price } \\
\text { (FCFA/kg) }\end{array}$ & $\begin{array}{l}\text { Price } \\
\text { (USD/kg) }\end{array}$ \\
\hline Sorghum bicolor L.) Moench & Lv & 50 & 4,000 & 7.12 \\
\hline Senna occidentalis (L.) Link & $\mathrm{Se}$ & 250 & 2,800 & 4.98 \\
\hline Senna angustifolia Vahl & TB & 23.86 & 2,096 & 3.73 \\
\hline Gardenia aqualla Stapf. \& Hutch. & TB & 100 & 2,000 & 3.56 \\
\hline Securidaca longepedunculata Fres. & $\mathrm{Rt}$ & 400 & 1,250 & 2.22 \\
\hline Abrus precatorius $\mathrm{L}$. & $\mathrm{Rt}$ & 160 & 1,250 & 2.22 \\
\hline Pavetta corymbosa (DC.) F. N. Williams & St & 50 & 1,000 & 1.78 \\
\hline Cocos nucifera L. & $\mathrm{Rt}$ & 530 & 943 & 1.68 \\
\hline Senna occidentalis (L.) Link & $\mathrm{Rt}$ & 250 & 800 & 1.42 \\
\hline Tetrapleura tetaptera (Schumach. et Thonn.) Taub. & $\mathrm{Fr}$ & 750 & 667 & 1.19 \\
\hline Acacia nilotica (L.) Willd. ex Delile & $\mathrm{Fr}$ & 950 & 526 & 0.94 \\
\hline Rauvolfia vomitoria Afzel. & $\mathrm{Rt}$ & 600 & 500 & 0.89 \\
\hline Jatropha gossypifolia L. & St & 100 & 500 & 0.89 \\
\hline Alstonia boonei De Wild. & $\mathrm{Rt}$ & 1,250 & 400 & 0.71 \\
\hline Chassalia kolly (Schumach.) Hepper & $\mathrm{Rt}$ & 500 & 400 & 0.71 \\
\hline Lannea kerstingii A. Rich. & TB & 600 & 333 & 0.59 \\
\hline Bridelia ferruginea Benth. & TB & 350 & 286 & 0.51 \\
\hline Uvaria chamae P. Beauv. & Rt & 350 & 286 & 0.51 \\
\hline Phyllanthus amarus Sch. et Th. & Wp & 190 & 263 & 0.47 \\
\hline Gomphrena celosioides Mart. & Wp & 1,230 & 244 & 0.43 \\
\hline Cassytha filiformis $\mathrm{L}$. & Wp & 440 & 227 & 0.40 \\
\hline Fluggea virosa (Roxb. ex Willd.) Voigt & St & 470 & 213 & 0.38 \\
\hline Paullinia pinnata $\mathrm{L}$. & $\mathrm{Rt}$ & 3,450 & 203 & 0.36 \\
\hline Hibiscus sabdariffa L. var. Sabdariffa & St & 500 & 200 & 0.36 \\
\hline Cymbopogon citratus (DC.) Stapf & Lv & 250 & 200 & 0.36 \\
\hline Hibiscus sabdariffa L. & St & 1,240 & 161 & 0.29 \\
\hline Senna rotondifolia L. & Wp & 475 & 158 & 0.28 \\
\hline Pterocarpus erinaceus Poir. & TB & 1,350 & 148 & 0.26 \\
\hline Sanseviera liberica Ger. and Labr. & $\mathrm{Rh}$ & 700 & 143 & 0.25 \\
\hline Paullinia pinnata L. & St & 390 & 128 & 0.23 \\
\hline Spathodea campanulata P. Beauv. & St & 800 & 125 & 0.22 \\
\hline Spondia mombin L. & St & 200 & 125 & 0.22 \\
\hline $\begin{array}{l}\text { Lactuca taraxacifolia (Willd.) Schumach. ex } \\
\text { Hornem. }\end{array}$ & Wp & 850 & 118 & 0.21 \\
\hline Acanthospermum hispidum DC. & St & 240 & 104 & 0.19 \\
\hline Vitellaria paradoxa C.F.Gaertn. & TB & 1,950 & 103 & 0.18 \\
\hline Waltheria indica $\mathrm{L}$. & St & 250 & 100 & 0.18 \\
\hline Mangifera indica L. & TB & 2,030 & 99 & 0.18 \\
\hline Dialium guineense Willd. & St & 775 & 97 & 0.17 \\
\hline Dichapetalum madagascariense (DC.) Keay. & St & 1,050 & 95 & 0.17 \\
\hline Morinda lucida Benth. & St & 1,050 & 95 & 0.17 \\
\hline Vitex doniana Sweet & TB & 2,250 & 89 & 0.16 \\
\hline Sarcocephalus latifolius (Smith) Bruce & TB & 1,800 & 83 & 0.15 \\
\hline Kigelia africana (Lam.) Benth. & $\mathrm{Fr}$ & 2,500 & 80 & 0.14 \\
\hline Cola millenii K. Schum. & St & 875 & 57 & 0.10 \\
\hline Anthocleista nobilis Afzel. ex. R. Br. & TB & 2,100 & 48 & 0.08 \\
\hline Anchomanes difformis (Blume) Engl. & Tu & 4,600 & 43 & 0.08 \\
\hline Piliostigma thonningii (Sch.) Miln. Redh. & St & 600 & 42 & 0.07 \\
\hline Lippia multiflora Moldenke & St & 2,950 & 34 & 0.06 \\
\hline Parkia biglobosa (Jacq.) Benth. & TB & 1,900 & 13 & 0.02 \\
\hline
\end{tabular}




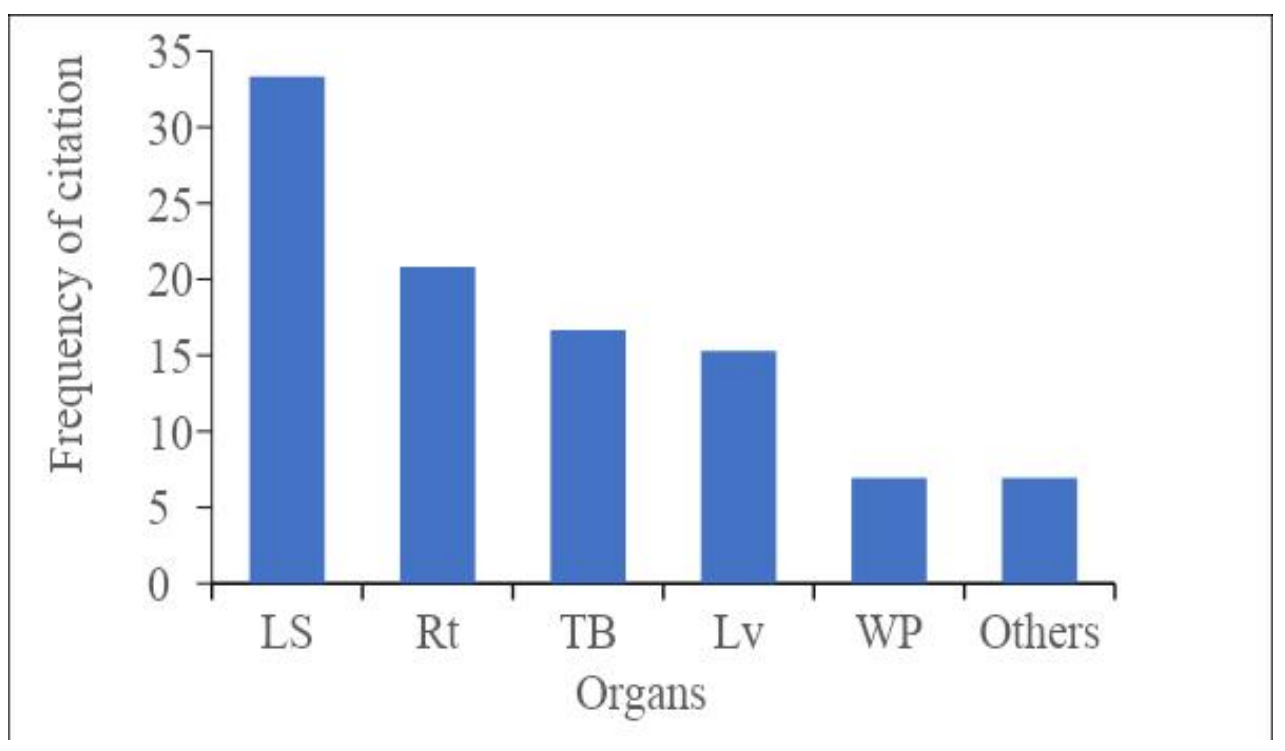

Fig. 4. Frequency of plant organs use

Lv: leave; LS: leafy stem; Rt: root; TB: trunk bark; WP: whole plant; Others: fruit, seed, and tuber

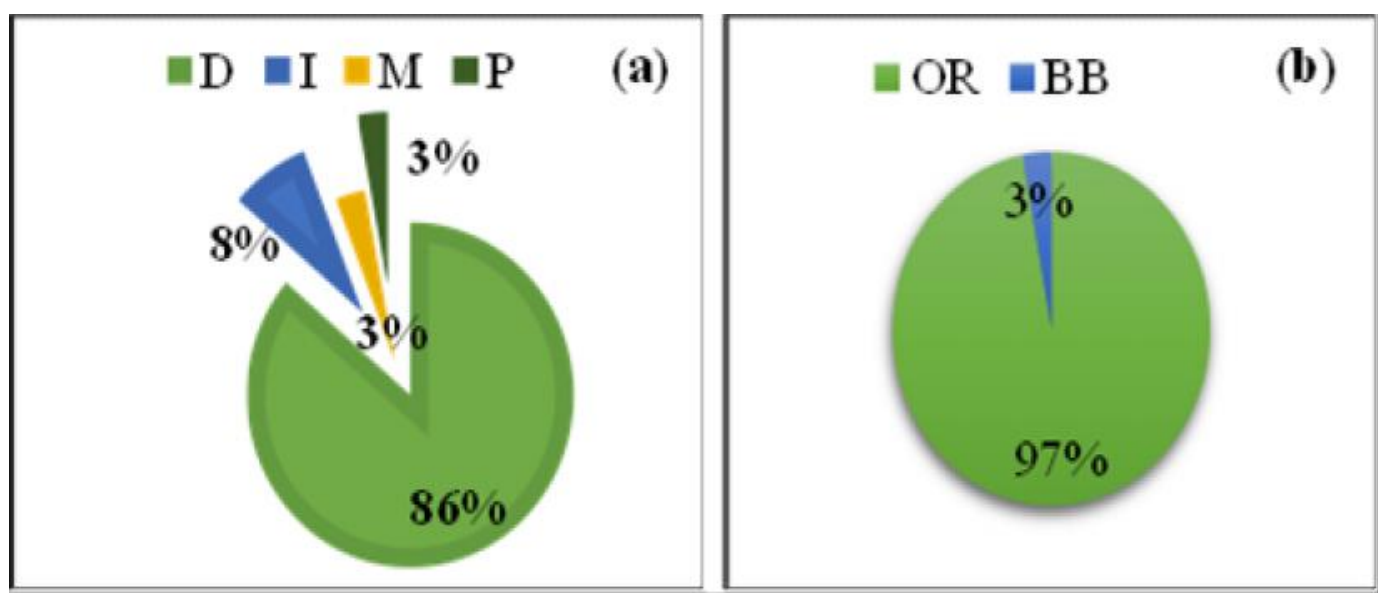

Fig. 5. Distribution of recipe formulation (a) and administration (b) modes $D$ : decoction; I: infusion; M: maceration; P: powder; OR: oral route; BB: body bath

\section{CONCLUSION}

Through the ATRM method, this study was the very first to be applied in Africa and in Togo, particularly for the inventory of plants with antihypertensive properties. It is of great interest for the effective management of hypertension as it allowed identifying directly in the herbalist 62 plant species related to it. Among these species, Alstonia boonei, Lannea kerstingii, Cola millenii, Pavetta corymbosa, Uvaria chamae, Senna occidentalis and Securidaca longepedunculata, which already most used in the management of hypertension, are strongly threatened through the sale of their vital organs. These species deserve better management, hence the urgency to act if we want to preserve the biodiversity they shelter and the services they provide to human beings. It is recommended to:

- Establishing awareness sessions for local populations on the importance of endangered plants.

- To carry out continuous training on good practices for the harvesting and cultivation of endangered plants for the benefit of home traditional healers and herbalists.

- Consolidate regulation and control of plant resource exploitation 


\section{ACKNOWLEDGEMENTS}

The authors are grateful to Jean AZANKPO for his immeasurable support during the data collection. Their sincere appreciation goes to the herbalists of the city of Lomé for their excellent collaboration.

\section{COMPETING INTERESTS}

Authors have declared that no competing interests exist.

\section{REFERENCES}

1. Niakara A, Nebie LVA, Zagre NM, Ouedraogo NA, Megnigbeto AC. Connaissances d'une population urbaine sur l'hypertension artérielle: Enquête prospective menée à Ouagadougou, Burkina Faso . Bull Soc Pathol Exot. 2003;96(3):219-22.

2. Addo J, Smeeth L, Leon DA. Hypertension in sub-Saharan Africa: A systematic review. Hypertension. 2007;50(6):1012-8.

3. Tra Bi F, Irié G, N'Gaman K, Mohou C. Études de quelques plantes thérapeutiques utilisées dans le traitement de l'hypertension artérielle et du diabète: Deux maladies émergentes en Côte d'Ivoire. Sci Nat. 2008;5:39-48.

4. Gbekley HE, Karou SD, Katawa G, Tchacondo T, Ameyapoh Y, Simpore J. Ethnobotanical survey of medicinal plants used in the management of hypertension in the maritime region of Togo. Afr $\mathrm{J}$ Tradit Complement Altern Med. 2018;15:85-97.

5. Fourcade L, Paule P, Mafart B. Hypertension arterielle en Afrique Subsaharienne- actualités et perspectives. Médecine Tradit. 2007;67:559-67.

6. Baragou S, Pio M, Atta P, Soussou B. Prevalence de l'hypertension arterielle et des autres facteurs de risque cardiovasculaire en milieu professionnel Ouest Africain (Togo). J la Rech Sci l'Université Lomé [Internet]. [cited 2019 Apr 10]. 2012;14(2):105-9.

Available:https://www.ajol.info/index.php/jrs ul/article/view/138746

7. Houinato DS, Gbary AR, Houehanou YC, Djrolo F, Amoussou M, Segnon-Agueh J, Kpozehouen A, Salamon R. Prevalence of hypertension and associated risk factors in Benin. Rev Epidemiol Sante Publique. 2012;60(2):95-102.
8. Ministère de la Santé BF. Enquête nationale sur la prévalence des principaux risques communs aux maladies non transmissibles au Burkina Faso. 2014;78.

9. Dzudie A, Kengne AP, Muna W, Ba $\mathrm{H}$, Menanga A, Kouam CK, Abah J, et al. Prevalence, awareness, treatment, and control of hypertension in a self-selected sub-Saharan African urban population: A cross-sectional study. BMJ Open. 2012;2(4).

10. Doulougou $B$, Kouanda $S$, Bado $A$, Nikièma L, Zunzunegui MV. Hypertension in the adult population of Kaya health and demographic surveillance system in Burkina Faso: Prevalence and associated factors. Int J Trop Dis Heal. 2014;4(1):94110.

11. Damasceno A, Cotter G, Dzudie A, Sliwa K, Mayosi BM. Heart Failure in SubSaharan Africa: Time for Action. J Am Coll Cardiol. 2007;50(17):1688-93.

12. Tokoudagba J, Chabert P, Auger C, Gom SN, Gbenou J, Moudachirou M, SchiniKerth V, Lobstein A. Recherche de plantes à potentialités antihypertensives dans la biodiversité béninoise. Ethnopharmacologia. 2009;44:32-41.

13. Aburjai T, Hudaib M, Tayyem R, Yousef M, Qishawi M. Ethnopharmacological survey of medicinal herbs in Jordan, the Ajloun Heights region. J Ethnopharmacol. 2007;110(2):294-304.

14. Koudouvo K, Denou A, Esseh K, Sanogo $\mathrm{R}$, Essien K, Diallo D, Kokou K, Tozo S, Aklikokou K, Aguiyi J, Gbéassor M. Ethnobotanical Survey of Endangered Antimalarial and Analgesic Plants of Togo for the Safeguard of the Medicinal Biodiversity. J Agric Ecol Res Int. 2017;12(2):1-9.

15. Karou SD, Tchacondo T, Agassounon M, Tchibozo D, Abdoul-rahaman S, Anani K, et al. Ethnobotanical study of medicinal plants used in the management of diabetes mellitus and hypertension in the Central Region of Togo. Pharm Biol. 2011;49(12):1286-1297.

16. Koudouvo K. Contribution à la recherche sur les plantes médicinales à propriété antipaludique du Togo [Internet]. Université de Lomé en Biologie de Développement. Option: Ethnobotanique et Pharmacologie des Substances Naturelles; 2009. [cited 2019 Apr 16]. 
Available : https://www.google.com/search

17. Koudouvo K, Karou SD, Ilboudo DP, Kokou $\mathrm{K}$, Essien $\mathrm{K}$, Aklikokou $\mathrm{K}$, et al. In vitro antiplasmodial activity of crude extracts from Togolese medicinal plants. Asian Pac J Trop Med. 2011;4(2):129-32.

18. Dénou $A$, Koudouvo $K$, Togola $A$, Aziati $\mathrm{KY}$, Esseh J, Ajavon CA, Essien $\mathrm{K}$, et al. Traditional knowledge on antimalarial plants having analgesic properties, used in Togo Maritime Region. J Ethnobiol Tradit Med. 2016;126:1160-70.

19. Gbekley EH, Karou DS, Gnoula C, Agbodeka K, Anani K, Tchacondo T, et al. Étude ethnobotanique des plantes utilisées dans le traitement du diabète dans la médecine traditionnelle de la région Maritime du Togo. Pan Afr Med J. 2015;20:437.

20. Klotoé JR, Ajavon CA, Koudouvo K, Dénou A, Aziati-yovoh $\mathrm{T}$, Esseh K. Ethnopharmacological Survey of Plants used for the Treatment of Malaria Anemia in the Maritime Region of Togo. Asian $\mathrm{J}$ Ethnopharmacol Med Foods. 2018;4:3-8.

21. APG III. La classification phylogénétique, modifiée de l'APG II 2003: An update of Angiosperms Phylogeny Grou classification for the orders an families of flowerering plants. Bot J Linn Soc [Internet]. [cited 2019 Apr 14]; 2009;141:399-436.

Available: https://www.google.com/search

22. Akoegninou A, Van der Burg WJ, Van Der Maesan L, Adjakidje V EJ, Sinsin B, Yédomonhan $\mathrm{H}$. Flore analytique du Bénin. Cotonou \& Wageningen, Backhuys Publishers. 2006;1034.

23. Gbolade A. Ethnobotanical study of plants used in treating hypertension in Edo State of Nigeria. J Ethnopharmacol [Internet]. 2012;144(1):1-10.

Available:http://dx.doi.org/10.1016/j.jep.201 2.07.018

24. Denver D, Diana G, Quinton J. Author's Accepted Manuscript. J Ethnopharmacol [Internet]; 2016.

Available:http://dx.doi.org/10.1016/j.jep.201 6.10 .063

25. Tsabang $\mathrm{N}$, Yedjou CG, Tchounwou P. Phytotherapy of High Blood Pressure in Three Phytogeographic Regions of Cameroon. Pharm Anal Acta. 2017;8(1):112.

26. Agbodjogbe WKDD, Aikpe JFA, Ayedoun MA, Assogba FM, Dansou PH, Gbenou JD. Diuretic and natriuretic activities from ten medicinal plants used in south Benin. J Chem Pharm Res [Internet]. 2015;7(12):1145-52.

Available:http://jocpr.com/vol7-iss12-2015/ JCPR-2015-7-12-1145-1152.pdf

27. Ladeji O, Okoye ZSC, Uddoh F. Effects of Vitex doniana stem bark extract on Blood Pressure. Phyther Res [Internet]. [cited 2019 Apr 20]. 1996;10(3):245-7.

Available from: http://doi.wiley.com/10.1002

28. Etou Ossibi WA, Elion Itou RDG, Nzonzi J, Nsonde Ntandou GF, Dimo T, Ouamba JM, Abena AA. Effets de l'extrait aqueux de Lippia multiflora Moldenke (Verbenaceae) sur la pression artérielle, la fréquence cardiaque et les ondes de l'électrocardiogramme chez le rat normotendu. Rev CAMES- Série Pharm Méd Trad Afr. 2014;17(1):1-9.

29. Compaore S, Belemnaba L, Houkpevi A, Idohou R, Zerbo I, Ouedraogo S, Thiombiano A. Diversity of plants used in the management of hypertension by three associations of traditional healers along climate gradient in Burkina Faso. Adv Tradit Med; 2020.

30. Kassi Y, Aka KJ, Abo KJ-C, Méa A, Néné Bi SA, Ehilé EE. Effet antihypertensif d'un extrait aqueux d'écorce de tronc de Parkia biglobosa (Mimosaceae) sur la pression artérielle de lapin. Sci Nat. 2008;5(2):13343.

31. Kane MO, Sarr M, Gueye papa M, Ndiaye CAB, Diaw M, Ba A, Sar FB, Sall/Diallo A. Effets relaxants vasculaires d'un extrait hydroalcoolique d'écorce de Parkia biglobosa (mimosaceae). Sci Ed Mersenne. 2009;2(090901):1-12.

32. Ouédraogo $S$, Somé $N$, Ouattara $S$, Kini FB, Traore A, Bucher B, and Guissou IP. Acute Toxicity and vascular properties of seed of Parkia biglobosa (Jacq) R. Br Gift (Mimosaceae) on rat aorta. Afr $\mathrm{J}$ Tradit Complement Altern Med. 2012;9:260-5.

33. Belemnaba L, Ouédraogo $S$, Nitiéma $M$, Chataigneau T, Guissou IP, Schini-Kerth VB, Bucher B, Auger C. An aqueous extract of the Anogeissus leiocarpus bark $(A E A L)$ induces the endotheliumdependent relaxation of porcine coronary artery rings involving predominantly nitric oxide. J Basic Clin Physiol Pharmacol. 2018;29(6):599-608.

34. Wangny AA, Ouattara $\mathrm{T}$, Abrou N, N'guessan K. Etude Ethnobotanique des Plantes Utilisées en Médecine Traditionnelle dans le Traitement de 
l'Hypertension Artérielle chez les Peuples du Département de Divo, (Centre-ouest, Côte d'Ivoire). Eur Sci J ESJ. 2019;15(24):384-407.

35. Traore L, Ouedraogo I, Ouedraogo A, Thiombiano A et al. Perceptions, usages et vulnérabilité des ressources végétales ligneuses dans le Sud-Ouest du Burkina Faso. Int J Biol Chem Sci. 2011;5(1):25878.

36. Belemnaba L, Nitiema $\mathrm{M}$, Traoré $\mathrm{S}$, Somé N, Traore A, Ouédraogo S, Guissou IP. Recherche de plantes à potentialités antihypertensives dans la biodiversité du Burkina Faso. Rev CAMES - Série Pharm Méd Trad Afr. 2014;17(1):33-40.

37. Nguemo Dongock D, Bonyo Laohudumaye A, Mapongmestem PM, Bayegone E. Etude ethnobotanique et phytochimique des plantes médicinales utilisées dans le traitement des maladies cardiovasculaires à Moundou (Tchad). Int $\mathrm{J}$ Biol Chem Sci. 2018;12(1):203.

38. Salhi S, Fadli M, Zidane L, Douira A. Etudes floristique et ethnobotanique des plantes médicinales de la ville de Kénitra (Maroc). Lazaroa. 2010;31:133-46.

39. Kokou K, Adjossou K, Kokutse AD. Considering sacred and riverside forests in criteria and indicators of forest management in low wood producing countries: The case of Togo. Ecol Indic. 2008;8:158-69.

40. Akpavi S, Wala K, Gbogbo KA, Odah K, Woegan YA, Batawila K, et al. Distribution spatiale des plantes alimentaires mineures ou menacées de disparition au Togo: Un indicateur de l'ampleur de leur menace. Acta Bot Gall. 2012;159(4):411-32.

41. Atsri HK, Konko Y, Cuni-sanchez A, Abotsi $\mathrm{KE}$, Kokou K. Changes in the West African forest-savanna mosaic, insights from central Togo. PLoS One. 2018;5:1-19. 
APPENDIX

Species identified by the ATRM method for the management of hypertension

\begin{tabular}{|c|c|c|c|c|c|c|}
\hline Species & Family & Local name & $\mathbf{F C}$ & Organs & $\begin{array}{l}\text { Preparation } \\
\text { mode }\end{array}$ & $\begin{array}{l}\text { Administration } \\
\text { route }\end{array}$ \\
\hline Acanthospermum hispidum DC. & Asteraceae & \multicolumn{2}{|c|}{ Afegban; Dougban4.92 } & WP & $\mathrm{D}$ & OR \\
\hline Alstonia boonei De Wild. & Apocynaceae & $\begin{array}{l}\text { Nyami Dua; } \\
\text { Siaketekre }\end{array}$ & 0.55 & TB & $\mathrm{D}$ & OR \\
\hline $\begin{array}{l}\text { Anchomanes difformis (Blume) } \\
\text { Engl. }\end{array}$ & Araceae & - & 1.64 & Tu & $\mathrm{D}$ & OR \\
\hline $\begin{array}{l}\text { Anogeissus leiocarpa (DC.) Guill. } 8 \\
\text { Perr. }\end{array}$ & \&Combretaceae & Hehetsi; Hehe & 0.55 & TB & $\mathrm{D}$ & OR \\
\hline $\begin{array}{l}\text { Bambusa vulgaris Schrad ex. } \\
\text { Wendel }\end{array}$ & Poaceae & $\begin{array}{l}\text { Pamplo; } \\
\text { pamploti }\end{array}$ & 0.55 & St & $\mathrm{D}$ & OR \\
\hline Bridelia ferruginea Benth. & Phyllanthaceae & Kamati; Hlihoin & 0.55 & TB & $\mathrm{D}$ & OR \\
\hline Byrsocarpus coccineus Sch. et Th. & Connaraceae & - & 0.55 & St & $\mathrm{D} ; \mathrm{I}$ & OR \\
\hline Calotropis procera (Aiton) R.Br. & Apocynaceae & $\begin{array}{l}\text { Adzema; } \\
\text { Gbolobavi }\end{array}$ & 0.55 & Rt & $\mathrm{D}$ & OR \\
\hline $\begin{array}{l}\text { Clausena anisata (Wild.) Hook. } \\
\text { F.ex Benth. }\end{array}$ & Rutaceae & Eyra; Iratsi & 0.55 & Lv & Po & OR \\
\hline Cocos nucifera L. & Arecaceae & $\begin{array}{l}\text { Yovoninti; } \\
\text { Yevunetsi }\end{array}$ & 1.64 & $\mathrm{Rt}$ & $\mathrm{D}$ & OR \\
\hline Cola millenii K. Schum. & Malvaceae & $\begin{array}{l}\text { Assiviatoe; } \\
\text { Kessedui }\end{array}$ & 0.55 & St & $\mathrm{D}$ & OR \\
\hline Crataeva religiosa Forst & Capparaceae & $\begin{array}{l}\text { Wataïzan; } \\
\text { Ontoezin }\end{array}$ & 1.64 & St & $\mathrm{D}$ & OR \\
\hline Cymbopogon citratus (DC.) Stapf & Poaceae & Tsigbe; Gbehoin & 2.19 & St & $D ; I$ & OR; BB \\
\hline $\begin{array}{l}\text { Cymbopogon giganteus (Hochst.) } \\
\text { Chiov. }\end{array}$ & Poaceae & - & 0.55 & Lv & D & $\mathrm{BB}$ \\
\hline $\begin{array}{l}\text { Dichapetalum madagascariense } \\
\text { (DC.) Keay. }\end{array}$ & Dichapetalaceae & $\begin{array}{l}\text { Atihali; } \\
\text { Tchokpleti }\end{array}$ & 2.19 & St & $\mathrm{D}$ & OR \\
\hline Eucalyptus citriodora Hooker & Myrtaceae & Tilo; Ekalypti & 1.09 & St & $\mathrm{D}$ & OR \\
\hline $\begin{array}{l}\text { Gardenia ternifolia Schumach. \& } \\
\text { Thonn. Ssp. ternifolia }\end{array}$ & Rubiaceae & Flifeti; Lanmaleti & 1.64 & St & $\mathrm{D}$ & OR \\
\hline Gomphrena celosioides Mart. & Amaranthaceae & $\begin{array}{l}\text { Papataxe; } \\
\text { Gnagantahé }\end{array}$ & 0.55 & WP & $\mathrm{D}$ & BB \\
\hline Hibiscus sabdariffa L. & Malvaceae & Gnatoxe; Gnatu & 1.64 & St & $\mathrm{D}$ & BB \\
\hline Hymenocardia acida Tul. & Phyllanthaceae & - & 0.55 & $\mathrm{Rt}$ & $\mathrm{D}$ & BB \\
\hline Jatropha gossypifolia L. & Euphorbiaceae & Babatidjin; Kpoti & 0.55 & St & $\mathrm{D}$ & OR \\
\hline Khaya anthoteka C. DC. & Meliaceae & & 0.55 & TB & $\mathrm{M}$ & $\mathrm{BB}$ \\
\hline $\begin{array}{l}\text { Khaya senegalensis (Desr.) A. } \\
\text { Juss. }\end{array}$ & Meliaceae & $\begin{array}{l}\text { Mahogen; } \\
\text { Mahogani }\end{array}$ & 0.55 & TB & M & OR \\
\hline Kigelia africana (Lam.) Benth. & Bignoniaceae & $\begin{array}{l}\text { Vinokpa; } \\
\text { Gnakpekpe }\end{array}$ & 1.09 & $\mathrm{Fr}$ & $\mathrm{D}$ & OR; BB \\
\hline $\begin{array}{l}\text { Lactuca taraxacifolia (Willd.) } \\
\text { Schum. }\end{array}$ & Asteraceae & - & 0.55 & St & $\mathrm{D}$ & OR \\
\hline Lannea kerstingii A. Rich. & Anacardiaceae & $\begin{array}{l}\text { Melonkou; } \\
\text { Monlonkou }\end{array}$ & 3.83 & TB & $\mathrm{D}$ & OR \\
\hline Lippia multiflora Moldenke & Verbenaceae & Avudati; Avoloti & 23.50 & Lv & $\mathrm{D} ; \mathrm{I} ; \mathrm{M}$ & OR; BB \\
\hline Mangifera indica L. & Anacardiaceae & Mongoti; Atontsi & 1.09 & TB & $\mathrm{D}$ & $\mathrm{BB}$ \\
\hline $\begin{array}{l}\text { Maytenus senegalensis (Lam.) } \\
\text { Exell. }\end{array}$ & Celastraceae & - & 0.55 & Rt & $\mathrm{D}$ & $\mathrm{BB}$ \\
\hline Mezoneuron benthamianum Baill. & Fabaceae & - & 0.55 & Rt & $\mathrm{D}$ & BB \\
\hline Morinda lucida .Benth. & Rubiaceae & Zanklan; Dadaklar & $\mathrm{n} 0.55$ & Rt & $\mathrm{D}$ & BB \\
\hline Moringa oleifera L. & Moringaceae & Yovovigbe; Kpotsi & 1.64 & Lv & D; Po & OR \\
\hline Newbouldia laevis Seem. & Bignoniaceae & Kpatima; Kpoti & 0.55 & St & D & OR \\
\hline Oldenlandia corymbosa L. & Rubiaceae & Tsoèvissihin & 1.09 & WP & $\mathrm{D}$ & OR \\
\hline Parkia biglobosa (Jacq.) Benth. & Fabaceae & Ewati; Ewoti & 0.55 & TB & $\mathrm{D}$ & OR \\
\hline Paullinia pinnata $\mathrm{L}$. & Sapindaceae & $\begin{array}{l}\text { Assiviatoè; } \\
\text { Hokouika }\end{array}$ & 1.09 & $\mathrm{Rt} ; \mathrm{St}$ & D & OR \\
\hline $\begin{array}{l}\text { Pavetta corymbosa (DC.) F. N. } \\
\text { Williams }\end{array}$ & Rubiaceae & Sifafa; Siafati & 1.09 & St & $\mathrm{D}$ & OR \\
\hline Pavetta crassipes K.Schum. & Rubiaceae & Pagalagbe & 1.09 & St & $\mathrm{D}$ & OR \\
\hline Phyllanthus amarus Sch. et Th. & Phyllanthaceae & Tchekoulemègbè & 1.09 & WP & $\mathrm{D}$ & OR \\
\hline
\end{tabular}


Compaoré et al.; ARRB, 35(12): 98-111, 2020; Article no.ARRB.64157

\begin{tabular}{|c|c|c|c|c|c|c|}
\hline Species & Family & Local name & FC & Organs & $\begin{array}{l}\text { Preparation } \\
\text { mode }\end{array}$ & $\begin{array}{l}\text { Administration } \\
\text { route }\end{array}$ \\
\hline $\begin{array}{l}\text { Piliostigma thonningii (Sch.) Miln. } \\
\text { Redh. }\end{array}$ & Fabaceae & Klonti; Eklo & 2.19 & Lv & $\mathrm{D}$ & $\mathrm{BB}$ \\
\hline Rauvolfia vomitoria Afzel. & Apocynaceae & - & 0.55 & $\mathrm{Rt}$ & D & BB \\
\hline $\begin{array}{l}\text { Rourea coccineus Schum et } \\
\text { Thonn. }\end{array}$ & Connaraceae & $\begin{array}{l}\text { Tomègavi; } \\
\text { Letuiletui }\end{array}$ & 0.55 & St & $\mathrm{D}$ & BB \\
\hline Sanseviera liberica Ger. and Labr. & Agavaceae & Yodobou; Yoboo & 2.19 & $\mathrm{Rt}$ & D & BB \\
\hline $\begin{array}{l}\text { Sarcocephalus latifolius (Smith) } \\
\text { Bruce }\end{array}$ & Rubiaceae & Nyimon; Vevitsi & 1.64 & Rt & $\mathrm{D}$ & OR \\
\hline Securidaca longepedunculata Fres & Polygalaceae & Etritou; Kpeta & 1.09 & $\mathrm{Rt}$ & D & BB \\
\hline Securinega virosa (Reyb.) Baill. & Euphorbiaceae & $\begin{array}{l}\text { Hesre; Tsaka- } \\
\text { tsaka }\end{array}$ & 1.09 & St & $\mathrm{D}$ & OR \\
\hline Senna angustifolia Vahl & Fabaceae & \multicolumn{2}{|c|}{ Agoègbe; Asragbe 0.55} & Lv & M & OR \\
\hline Senna occidentalis (L.) Link & Fabaceae & $\begin{array}{l}\text { Bessissan; } \\
\text { Avakofè }\end{array}$ & 1.64 & $\mathrm{Se}$ & $\mathrm{D}$ & OR \\
\hline Senna rotondifolia L. & Fabaceae & Azingbe; Zigbe & 1.64 & WP & D & OR \\
\hline Senna sieberiana DC. & Fabaceae & Gati-Gati & 3.28 & $\mathrm{Rt}$ & D; I & OR \\
\hline Sorghum bicolor L.) Moench & Poaceae & - & 0.55 & Lv & D & OR \\
\hline Spathodea campanulata P. Beauv. & Bignoniaceae & $\begin{array}{l}\text { Adassigolo; } \\
\text { Adatsigo }\end{array}$ & 0.55 & TB & $\mathrm{D}$ & OR \\
\hline Spondia mombin L. & Anacardiaceae & $\begin{array}{l}\text { Akoukondi; } \\
\text { Klikonti }\end{array}$ & 0.55 & Lv & $\mathrm{D}$ & OR \\
\hline $\begin{array}{l}\text { Tetrapleura tetraptera (Schumach. } \\
\text { et Thonn.) Taub. }\end{array}$ & Fabaceae & - & 0.55 & $\mathrm{Fr}$ & $\mathrm{D}$ & BB \\
\hline Uvaria chamae P. Beauv. & Annonaceae & \multicolumn{2}{|c|}{$\begin{array}{l}\text { Agbanlan; Gbana- } 8.20 \\
\text { gbana }\end{array}$} & $\mathrm{Rt}$ & $\mathrm{D}$ & OR \\
\hline Vitellaria paradoxa Gaertn C. F & Sapotaceae & - & 1.09 & TB & D & BB \\
\hline Vitex doniana Sweet & Lamiaceae & \multicolumn{2}{|c|}{ Fonyimakpa; Fonti 3.83} & TB & D & OR \\
\hline Waltheria indica L. & Malvaceae & $\begin{array}{l}\text { Adouwèti; } \\
\text { Adoufanti }\end{array}$ & 2.19 & St & $\mathrm{D}$ & OR \\
\hline $\begin{array}{r}\text { Lv: leave; LS: leafy stem; Rt: root; St: s } \\
\text { infus }\end{array}$ & $\begin{array}{l}\text { stem; TB: trunk bark } \\
\text { sion; M: maceration, }\end{array}$ & WP: whole plant; Fr: $f$ & fruit; $S \epsilon$ & e: seed; $T u$ & u: tuber; Rh: rhiz & ome; D: decoction; I: \\
\hline
\end{tabular}

Peer-review history:

The peer review history for this paper can be accessed here: http://www.sdiarticle4.com/review-history/64157 